\title{
STRUKTUR MODAL, INVESTMENT OPPORTUNITY SET, LIKUIDITAS DANNILAI PERUSAHAAN
}

\author{
Lia Uzliawati \\ Nana Nofianti \\ Dwi Putri Ratnasari
}

Universitas Sultan Ageng Tirtayasa

\begin{abstract}
This research aims to know the influence of variable capital structure as measured by debt to equity ratio (DER), the investment opportunity set as measured by the market to book ratio (MBA) asset and liquidity as measured by the current ratio (LIQ) against the value of the company that projected through the Price to Book Value (PBV) on the banking company listed on the Indonesia stock exchange (idx) of the period 2009-2013. This research population is 39 banking company. Purposive Sampling was used as sampling techniques and 29 companies selected as research samples. This study uses secondary data analysis and multiple regression. The results shows that the structure of capital and investment opportunity set has positive influence to the value of the company's liquidity and has no effect on the value of the company. While the size of the company as a control variable has a significant positive influence to the value of the company. Simultaneous capital structure, investment opportunity set and the liquidity effect significantly to the value of the company.
\end{abstract}

Keywords: capital structure, Investment Opportunity Set, Liquidity, size of the company and the value of the company.

\section{PENDAHULUAN}

Tujuan perusahaan menurut pandangan manajemen keuangan, pada dasarnya adalah mengoptimalkan nilai perusahaan. Nilai perusahaan merupakan persepsi investor terhadap tingkat keberhasilan perusahaan yang terkait erat dengan harga sahamnya (Sujoko dan Soebiantoro, 2007). Harga saham yang tinggi membuat nilai perusahaan juga tinggi dan meningkatkan kepercayaan pasar tidak hanya terhadap kinerja perusahaan saat ini namun juga pada prospek perusahaan di masa mendatang (Salvatore, 2005). Penelitian ini dilatarbelakangi oleh krisis ekonomi global yang terjadi di Eropa dan Amerika yang menimbulkan efek bagi Indonesia sebagai negara berkembang. Terlihat pada tahun 2009-2013 Indeks Harga Saham Gabungan (IHSG) di BEI yang mengalami fluktuasi (www.ojk.go.id, 2014). Dampak IHSG ini dialami pula oleh sektor perbankan di Indonesia. Hal ini ditandai dengan banyaknya perbankan yang mengalami penurunan nilai perusahaan.

Korespondensi dengan Penulis:

Lia Uzliawati: Telp. +62 81908858075

Email: uzliawati@yahoo.co.id 
Hasil olah data dengan menggunakan ukuran PBV dapat dilihat pada tabel 1 yaitu nilai kurang dari 1, didapati meningkat setiap tahunnya dari 20,7\% pada tahun 2009 ke 41,4\% pada tahun 2013. Banyaknya nilai PBV di bawah 1 menggambarkan bahwa saham perusahaan sektor perbankan dalam kondisi undervalue, yang artinya bahwa saham perusahaan dinilai lebih rendah dibandingkan nilai bukunya (Damodaran, 2002: 511). Padahal dengan semakin tingginya nilai PBV berarti pasar percaya akan prospek perusahaan tersebut. Sehingga, dengan menurunnya nilai PBV akan menimbulkan pengaruh pada menurunnya kesejahteraan para pemegang saham. Nilai perusahaan sangat penting karena mencerminkan kinerja perusahaan yang dapat mempengaruhi persepsi investor terhadap perusahaan. Peningkatan nilai perusahaan dapat tercapai apabila ada kerja sama antara manajemen perusahaan dengan pihak lain yang meliputi shareholder maupun stakeholder dalam membuat keputusan-keputusan keuangan dengan tujuan memaksimumkan kesejahteraan pemegang saham (Sukirni, 2012). Timbulnya konflik antara manajer dan pemegang saham menimbulkan agency problem. Agency problem inilah yang dapat menurunkan nilai perusahaan. Untuk mengurangi adanya agency problem perlu adanya biaya monitoring (agency cost).

Timbulnya agency cost merupakan suatu kondisi yang sangat kompleks dan sangat sulit untuk diminimalkan namun salah satu cara untuk mengontrol biaya tersebut adalah dengan mener- bitkan utang (Hardiningsih, 2009). Bringham dan Gapenski (1996) menjelaskan bahwa nilai perusahaan dapat ditingkatkan melalui kebijakan utang. Besarnya hutang yang digunakan oleh perusahaan adalah suatu kebijakan yang berhubungan dengan struktur modal. Teori struktur modal yang digunakan dalam penelitian ini adalah trade off theory. Hasil penelitian yang dilakukan oleh Oyerogba (2013), Bukit (2012), dan Chowdury dan Chowdury (2010) membuktikan teori tersebut bahwa struktur modal berpengaruh positif terhadap nilai perusahaan. Hal ini karena penggunaan hutang mempengaruhi beban bunga, sehingga semakin besar manfaat penghematan pajak maka semakin besar nilai perusahaan.

Selanjutnya, nilai perusahaan dapat ditingkatkan melalui investment opportunity set (IOS). Jika perusahaan mampu menciptakan keputusan investasi yang tepat maka aset perusahaan akan menghasilkan kinerja yang optimal sehingga memberikan sinyal positif bagi investor yang akan meningkatkan harga saham dan menaikkan nilai perusahaan (Prasetyo, 2011). Selain itu, Kallapur dan Trombley (2012) dan Kaestner dan Liu (1998) juga membuktikan bahwa IOS yang ada bagi perusahaan merupakan faktor utama yang menentukan pergerakan harga saham yang juga mempengaruhi nilai perusahaan.

Faktor selanjutnya yang juga dapat menjadi sinyal positif dan mempengaruhi nilai perusahaan adalah likuiditas. Agar para investor tertarik untuk

Tabel 1. Nilai perusahaan perbankan di Indonesia

\begin{tabular}{|c|c|c|c|c|c|c|c|c|c|c|}
\hline PBV & \multicolumn{2}{|c|}{2009} & \multicolumn{2}{c|}{2010} & \multicolumn{2}{c|}{2011} & \multicolumn{2}{c|}{2012} & \multicolumn{2}{c|}{2013} \\
\hline & $\begin{array}{c}\text { Jmlh } \\
\text { bank }\end{array}$ & $\%$ & $\begin{array}{c}\text { Jmlh } \\
\text { Bank }\end{array}$ & $\%$ & $\begin{array}{c}\text { Jmlh } \\
\text { bank }\end{array}$ & $\%$ & $\begin{array}{c}\text { Jmlh } \\
\text { bank }\end{array}$ & $\%$ & $\begin{array}{c}\text { Jmlh } \\
\text { bank }\end{array}$ & $\%$ \\
\hline$<1$ & 6 & $\mathbf{2 0 , 7}$ & 5 & $\mathbf{1 7 , 2}$ & 6 & $\mathbf{2 0 , 7}$ & 8 & $\mathbf{2 7 , 6}$ & 12 & $\mathbf{4 1 , 4}$ \\
\hline$=1$ & - & - & - & - & - & - & - & - & - & - \\
\hline$>1$ & 23 & $\mathbf{7 9 , 3}$ & 24 & $\mathbf{8 2 , 8}$ & 23 & $\mathbf{7 9 , 3}$ & 21 & $\mathbf{7 2 , 4}$ & 17 & $\mathbf{5 8 , 6}$ \\
\hline$\sum$ & 29 & $\mathbf{1 0 0}$ & 29 & $\mathbf{1 0 0}$ & 29 & $\mathbf{1 0 0}$ & 29 & $\mathbf{1 0 0}$ & 29 & $\mathbf{1 0 0}$ \\
\hline
\end{tabular}

Sumber: data diolah (2014) 
menginvestasikan dananya maka manajemen perlu untuk memberikan petunjuk kepada investor tentang bagaimana manajemen memandang prospek perusahaan yaitu dengan menjaga dan memperhatikan tingkat likuiditas perusahaan (Scott dan Bringham, 2008: 517). Hal ini diperkuat dengan penelitian yang dilakukan oleh Oyerogba (2013) dan Chowdhury dan Chowdhury (2010) yang menemukan hasil bahwa likuiditas yang diukur dengan current ratio mempunyai pengaruh yang positif dan signifikan terhadap nilai perusahaan. Sudah menjadi karakter investor untuk selalu meminati saham yang cenderung bersifat aman dan terus mengalami kenaikan.

Jensen dan Meckling (1976) menyatakan agency theory sebagai hubungan keagenan antara principal dan agen. Karena manajer diangkat oleh pemegang saham maka idealnya mereka bertindak yang terbaik untuk kepentingan pemegang saham namun dalam praktek sering terjadi konflik antara kedua pihak tersebut yang dinamakan agency problem (Martono dan Harjito, 2005: 11). Agency problem menurut Jansen dan Meckling (1976) menimbulkan dua permasalahan yaitu konflik kepentingan dan asimetri informasi. Terjadinya agency problem dapat menurunkan nilai perusahaan.

Trade-off theory menyebutkan bahwa kenaikan penggunaan hutang akan meningkatkan manfaat penghematan pajak dari hutang dan selanjutnya akan meningkatkan nilai perusahaan selama struktur modal tersebut belum mancapai titik optimal (Brigham \& Houston, 2009:620). Semakin besar penggunaan utang, maka semakin besar keuntungan dari penggunaan utang, namun present value biaya financial distress dan present value biaya agency juga meningkat bahkan lebih besar Atmaja, 2008:258).

Scott dan Brigham (2008:517) mengatakan bahwa untuk mengurangi adanya asimetri informasi maka manajemen berusaha untuk memberikan sinyal kepada investor. Sinyal ini merupakan sebuah tindakan yang diambil oleh manajemen per- usahaan yang memberikan petunjuk kepada investor tentang bagaimana manajemen memandang prospek perusahaan. Informasiyang diberikan oleh manajemenbertujuan untukmempertahankanminat investordi perusahaan.

\section{HIPOTESIS}

Struktur modal adalah perimbangan antara penggunaan modal pinjaman yang terdiri dari: utang jangka pendek yang bersifat permanen, utang jangka panjang dengan modal sendiri yang terdiri dari: saham preferen dan saham biasa (Dermawan, 2010:213). Hasil penelitian Oyerogba (2013) menunjukkan bahwa penggunaan hutang mempengaruhi beban bunga, sehingga semakin besar manfaat penghematan pajak karena penggunaan utang maka semakin besar nilai perusahaan. Hasil penelitian serupa juga ditemukan oleh Chowdury dan Chowdury (2010) yang membuktikan bahwa struktur modal berpengaruh positif signifikan terhadap nilai perusahaan. Selain itu Mardiyati, Ahmad dan Putri (2012) menyebutkan manajer bisa menggunakan utang yang lebih banyak, yang nantinya berperan sebagai sinyal yang lebih terpercaya karena perusahaan yang meningkatkan utang bisa dipandang sebagai perusahaan yang yakin dengan prospek perusahaan di masa yang akan datang dan risiko bisnis yang rendah.

H1: Struktur modal berpengaruh positif terhadap nilai perusahaan

Adam dan Goyal (2000) menyebutkan bahwa investment opportunity set (IOS) memainkan peranan penting di dalam keuangan perusahaan dalam kaitannya dengan pencapaian tujuan perusahaan melalui peningkatan nilai perusahaan. IOS menurut Myers (1977) adalah kombinasi antara aktiva yang dimiliki perusahaan (assets in place) dan pemilihan investasi pada masa yang akan datang dengan net present value positif. Penambahan IOS dapat mening- 
katkan nilai perusahaan. Hal ini karena investor percaya bahwa perusahaan yang meningkatkan IOS-nya, memiliki prospek yang bagus di kemudian hari, sehingga berinvestasi pada saham perusahaan tersebut akan menghasilkan return yang lebih tinggi yang akan meningkatkan nilai perusahaan (Pratiska, 2012 dan Yuliani et al 2012).

H2: IOS berpengaruh positif terhadap nilai perusahaan

Menurut Riyanto (2008:25) likuiditas berhubungan dengan masalah kemampuan suatu perusahaan untuk memenuhi kewajiban finansialnya yang harus segera dibayar. Chowdhury dan Chowdhury (2010) menemukan hasil bahwa likuiditas yang diukur dengan current ratio mempunyai pengaruh yang positif dan signifikan terhadap nilai perusahaan. Pratiwi (2011) juga menyebutkan bahwa likuiditas akan menghindarkan perusahaan dari risiko kebangkrutan dan investor akan menilai positif perusahaan dengan tingkat likuiditas yang baik karena memberikan jaminan keamanan bagi investasi yang dilakukan oleh investor pada perusahaan tersebut.

H3: Likuiditas berpengaruh positif terhadap nilai perusahaan

\section{METEDOLOGI}

Populasi dalam penelitian ini adalah perusahaanperbankankonvensionalyang terdaftardi Bursa EfekIndonesia(BEI) selama tahun 2009-2013, sebanyak 39 bank. Penelitian ini menggunakan teknik purposive sampling. Kriteriasampel yang digunakandalam penelitian ini yaitu perbankan konvensional yang listing di BEI dan menerbitkan laporankeuangan tahunan berturut-turutselama tahun2009-2013. Berdasarkan kriteria tersebut jumlahdata observasidiperoleh145laporan tahunan. Metode pengumpulan data dalam penelitian ini menggunakan data sekunder yang diambil dari laporan tahunan bank yang terdaftar di BEI pada tahun 2009-2013 yangberasal dari situs www. idx.co.id.

Teknik analisis data yang dilakukan dalam penelitian ini adalah dengan menggunakan analisis regresi berganda.

\section{HASIL PENELITIAN}

\section{Hasil statistik deskriptif}

Hasil analisis statistik deskriptif menunjukkan bahwa meskipun masih ada beberapa perbankan yang memiliki nilai perusahaan dibawah satu namun rata-rata nilai perusahaan perbankan di Indonesia adalah sebesar 1,905. Hal ini menunjukkan bahwa perbankan di Indonesia masih dalam kondisi yang cukup menguntungkan para pemegang sahamnya. Variabel struktur modal memiliki rata-rata sebesar 8,605 yang artinya perbankan di Indonesia lebih dominan menggunakan hutang daripada ekuitas dalam struktur modalnya. Hal ini dapat menjadi warning bagi perusahaan perbankan di Indonesia untuk memperhatikan besaran utang yang aman agar besarnya utang tidak menimbulkan financial distress dikemudian hari. Variabel IOS memiliki rata-rata sebesar 1,097 yang artinya perbankan di Indonesia memiliki kesempatan investasi yang relatif cukup banyak terhadap asset yang dimilikinya. Selanjutnya, variabel likuiditas memiliki rata-rata sebesar 1,116 yang artinya rata-rata kemampuan perbankan di Indonesia yang menjadi sampel penelitian ini dalam memenuhi kewajiban lancarnya sebesar 1,116 kali. Hasil statistic deskriptif ini mengindikasikan bahwa tingkat likuiditas perbankan di Indonesia sudah mencukupi. Merujuk pada Jumingan (2010: 23) yang mengatakan bahwa untuk perusahaan penghasil jasa angka current ratio 100\% dikatakan sudah mencukupi.

Berdasarkan hasil penelitian diketahui bahwa besarnya adjusted $\mathrm{R}^{2}$ adalah 0,919 , hal ini berarti 91,9\% variasi nilai perusahaan (PBV) dapat dijelaskan oleh variasi dari ketiga variabel independen 
struktur modal (DER), IOS (MBA) dan likuiditas (LIQ). Sedangkan sisanya $(100 \%-91,9 \%=8,1 \%)$ dijelaskan oleh sebab lain diluar model.

Model regresi

$$
\begin{aligned}
\text { PBV }= & -8,712+0,068 \text { DER }+8,082 \mathrm{IOS}-0,901 \mathrm{LIQ} \\
& +0,159 \mathrm{SIZE}
\end{aligned}
$$

Berdasarkan pengujian yang dilakukan untuk hipotesis pertama menunjukkan hasil bahwa struktur modal memiliki pengaruh positif dan signifikan terhadap nilai perusahaan karena $\mathrm{t}$ hitung 4,608 lebih besar dari t tabel 1,976 dengan tingkat signifikansi 0,000 lebih kecil dari $\alpha=5 \%$. Hal ini berarti bahwa hipotesis 1 dalam penelitian ini diterima.

Hipotesis kedua yang diajukan dalam penelitian ini menyatakan bahwainvestment opportunity set berpengaruh positif terhadap nilai perusahaan. Berdasarkan pengujian yang dilakukan, hasil penelitian ini menunjukkan bahwa investment opportunity set memiliki pengaruh positif dan signi-

Tabel 3. Operasionalisasi Variabel

\begin{tabular}{|l|l|l|}
\hline \multicolumn{1}{|c|}{ Variabel } & \multicolumn{1}{|c|}{ Pengukuran } & \multicolumn{1}{c|}{ Skala } \\
\hline Nilai Perusahaan & PBV $=\frac{\text { Harga pasar saham }}{\text { Nilai buku per lembar saham }}$ & Rasio \\
\hline Struktur Modal & DER $=\frac{\text { Total debt }}{\text { Total equity }}$ & Rasio \\
\hline IOS & $\begin{array}{l}\text { MBA ratio= [Nilai buku hutang + (Jmlh. lembar saham beredar } \\
\text { xharga saham penutupan) } \div \text { Total aset }\end{array}$ & Rasio \\
\hline Likuiditas & Current Ratio $=\frac{\text { Aktiva Lancar }}{\text { Hutang lancer }}$ & Rasio \\
\hline Ukuran perusahaan & Ukuran perusahaan = Log Total asset & Rasio \\
\hline
\end{tabular}

Tabel 4. Analisis regresi linier berganda

\begin{tabular}{ccccc}
\hline Model & Prediction sign & B & t-statistics & Sig. \\
Constant & & $-8,712$ & $-11,015$ & 0,000 \\
\hline & + & & & \\
DER & + & 0,068 & 4,608 & 0,000 \\
MBA & + & 8,082 & 35,220 & 0,000 \\
LIQ & + & $-0,901$ & $-1,604$ & 0,111 \\
SIZE & 145 & 0,159 & 4,213 & 0,000 \\
\hline N & 368,341 & & & \\
F & 0,000 & & & \\
Sig. & 0,959 & & & \\
R & 0,919 & & & \\
$\mathbf{R}^{2}$ & 0,916 & & & \\
Adj. $\mathbf{R}^{2}$ & & & & \\
\hline
\end{tabular}


fikan terhadap nilai perusahaan. Hal ini dibuktikan dengan thitung 35,220 lebih besar dari t tabel 1,976 dengan tingkat signifikansi sebesar 0,000 lebih kecil dari $\alpha=5 \%$. Dengan demikian hipotesis kedua dalam penelitian ini dapat diterima.

Adapun hipotesis ketiga yang diajukan dalam penelitian ini adalah likuiditas berpengaruh positif terhadap nilai perusahaan. Berdasarkan pengujian yang dilakukan, hasil penelitian ini menunjukkan bahwa likuiditas tidak memiliki pengaruh terhadap nilai perusahaan. Hal ini dibuktikan dengan $\mathrm{t}$ hitung -1,604 lebih besar dari $\mathrm{t}$ tabel 1,976 dengan tingkat signifikansi sebesar 0,111 lebih besar dari $\alpha=5 \%$. Dengan demikian hipotesis ketiga dalam penelitian ini ditolak.

Hasil penelitian ini konsisten dengan hasil penelitian yang dilakukan oleh Deemsomsak, et al (2004) dan Sheikh dan Wang (2012) yang membuktikan bahwa ukuran perusahaan berpengaruh terhadap struktur modal. Selain itu hasil penelitian Soliha dan Taswan (2002) dan Sujoko dan Soebiantoro (2007) menemukan bahwa ukuran perusahaan mempunyai pengaruh positif dan signifikan terhadap nilai perusahaan. Sehingga semakin besar ukuran suatu perusahaan maka akan semakin mudah mengakses ke pasar modal dan cepat untuk memperoleh pendanaan baik dari internal maupun eksternal. Hasil penelitian ini menunjukkan bahwa variabel ukuran perusahaan (size) dapat menjadi variabel kontrol dalam menjelaskan hubungan antara variabel independen terhadap variabel dependen. Hal ini didasari pada nilai koefisen hubungan yang positif dan signifikan dalam taraf signifikansi kurang dari 0,05. Adanya pengaruh positif mengindikasikan bahwa perusahaanperusahaan besar cenderung memberikan hasil operasi yang lebih besar sehingga memiliki kemampuan yang lebih besar untuk memberikan imbal balik investasi yang lebih menguntungkan dibandingkan dengan perusahaan-perusahaan kecil (Sofyaningsih dan Hardiningsih, 2011).

\section{PEMBAHASAN}

\section{Struktur Modal dan Nilai Perusahaan}

Berdasarkan pengujian yang dilakukan, hasil penelitian ini menunjukkan bahwa struktur modal memiliki pengaruh positif dan signifikan terhadap nilai perusahaan karena thitung 4,608 lebih besar dari t tabel 1,976 dengan tingkat signifikansi 0,000 lebih kecil dari $\alpha=5 \%$. Dengan demikian, hasil penelitian ini membuktikan bahwa struktur modal yang dimiliki perusahaan perbankan berpengaruh dalam meningkatkan nilai perusahaan perbankan di Indonesia. Kondisi perbankan di Indonesia cenderung menggunakan utang dalam struktur modalnya. Hal inilah yang mendorong peningkatan nilai perusahaan pada sektor perbankan di Indonesia. Penggunaan utang yang meningkat pada struktur modalnya akan meningkatkan nilai perusahaannya (Oyerogba, 2014 dan Chowdury dan Chowdury, 2010). Hasil penelitian ini mendukung pandangan trade-off theory yang menyatakan bahwa kenaikan penggunaan hutang akan meningkatkan manfaat penghematan pajak dari hutang dan selanjutnya akan meningkatkan nilai perusahaan (Brigham \& Houston, 2009: 620). Manfaat perlindungan pajak dapat meningkatkan nilai perusahaan karena dalam perhitungan pajak, bunga utang harus dikurangkan terlebih dahulu, maka ini berarti bahwa penggunaan utang akan mengakibatkan keringanan pajak untuk arus kas perusahaan. Terkait dengan signaling theory penambahan utang juga diartikan sebagai kemampuan perusahaan untuk membayar kewajibannya di masa yang akan datang atau risiko bisnis yang rendah, sehingga penambahan utang telah memberikan sinyal positif dalam meningkatkan nilai perusahaan (Bukit, 2012). Hasil penelitian ini inkonsisten dengan hasil penelitian yang dilakukan oleh Sofyaningsih dan Hardiningsih (2011) yang membuktikan bahwa kebijakan utang tidak berpengaruh terhadap nilai perusahaan. 


\section{Struktur Modal, Investment Opportunity Set, Likuiditas Dannilai Perusahaan}

Lia Uzliawati, Nana Nofianti, \& Dwi Putri Ratnasari

\section{Investment Opportunity Set dan Nilai Perusahaan}

Berdasarkan pengujian yang dilakukan, hasil penelitian ini menunjukkan bahwa investment opportunity set memiliki pengaruh positif dan signifikan terhadap nilai perusahaan. Hal ini dibuktikan dengan thitung 35,220 lebih besar dari $\mathrm{t}$ tabel 1,976 dengan tingkat signifikansi sebesar 0,000 lebih kecil dari $\alpha=5 \%$. Dengan demikian, hasil penelitian ini membuktikan bahwa investment opportunity set dapat meningkatkan nilai perusahaan di sektor perbankan yang terdaftar di Bursa Efek Indonesia. Hasil penelitian menunjukkan bahwa IOS sangat penting dalam memperbesar nilai perusahaan perbankan di Indonesia. Investor tertarik untuk menanamkan sahamnya disektor perbankan karena IOS memberikan dorongan yang sangat efektif untuk menunjukkan bahwa perbankan di Indonesia memiliki prospek yang bagus di kemudian hari, sehingga berinvestasi pada saham perusahaan perbankan akan menghasilkan return yang lebih tinggi yang pada akhirnya akan meningkatkan nilai perusahaan (Pratiska, 2012). Dengan demikian maka semakin besar IOS perbankan maka akan semakin besar pula nilai perusahaannya (Kallapur dan Trombley, 2001 dan Yuliani et al, 2012). Hasil penelitian ini inkonsisten dengan hasil penelitian yang dilakukan oleh Senda (2012) yang membuktikan bahwa investment opportunity set tidak berpengaruh terhadap nilai perusahaan.

\section{Likuiditas dan Nilai Perusahaan}

Berdasarkan pengujian yang dilakukan, hasil penelitian ini menunjukkan bahwa likuiditas tidak memiliki pengaruh terhadap nilai perusahaan. Hal ini dibuktikan dengan $t$ hitung -1,604 lebih besar dari t tabel 1,976 dengan tingkat signifikansi sebesar 0,111 lebih besar dari $\alpha=5 \%$. Dengan demikian, hasil penelitian ini membuktikan bahwa likui- ditas pada perusahaan perbankan tidak berpengaruh terhadap nilai perusahaan. Likuiditas yang diukur dengan current ratio menunjukkan tidak memiliki pengaruh terhadap nilai perusahaan. Hal ini mengindikasikan bahwa likuiditas perbankan yang terdaftar di BEI tidak terlalu dipertimbangkan pihak eksternal perusahaan dalam melakukan penilaian sebuah perbankan (Agustia, 2011 dan Nurhayati, 2013). Selain itu alasan yang juga dapat menyebabkan likuiditas tidak berpengaruh terhadap nilai perusahaan mungkin karena perbankan yang termasuk dalam BEI, diyakini sebagai perusahaan yang memiliki likuiditas baik, sehingga tidak ada keraguan lagi dari pihak eksternal terkait dengan kemampuan perbankan dalam melunasi kewajiban jangka pendeknya. Sehingga likuiditas bukanlah dorongan atau motivasi bagi investor untuk berinvestasi pada perusahaan perbankan di Indonesia. Hasil penelitian ini tidak konsisten dengan hasil penelitian yang dilakukan oleh Oyeroga (2013), Rompas (2013) dan Pratiwi (2011) yang membuktikan bahwa likuiditas berpengaruh terhadap nilai perusahaan.

\section{KESIMPULAN}

Berdasarkan hasil penelitian ini membuktikan bahwa struktur modal melalui kebijakan utang tidak hanya berfungsi sebagai sumber modal eksternal tetapi memberikan manfaat perlindungan pajak dan menjadi sinyal positif yang dapat meningkatkan nilai perusahaan. Investment Opportunity Set (IOS) memberikan dorongan yang sangat efektif untuk menunjukkan bahwa perbankan di Indonesia memiliki prospek yang bagus di kemudian hari, sehingga IOS mampu menambah nilai perusahaan perbankan yang terdaftar di BEI. Likuiditas perbankan yang terdaftar di BEI tidak terlalu dipertimbangkan pihak eksternal perusahaan dalam melakukan penilaian sebuah perbankan. Sehingga likuiditas tidak memiliki pengaruh terhadap nilai perusahaan perbankan. 


\section{Jurnal Keuangan dan Perbankan | KEUANGAN}

Vol. 20, No.2, Mei 2016: 195- 203

\section{SARAN}

Berikut ini beberapa saran yang dapat dijadikan pertimbangan untuk peneltian selanjutnya:

1) Penelitian selanjutnya diharapkan dapat menambahkan variable internal lainnya seperti profitabilitas,kebijakan dividen dan kepemilikan manajerial atau menambahkan variabel eksternal seperti tingkat suku bunga, keadaan pasar modal dan pertumbuhan pasaryang dapat meningkatkan nilai perusahaan.

2) Penelitian selanjutnya diharapkan tidak hanya pada perusahaan perbankan, tetapi dari sektor lainnya atau seluruh perusahaan yang listing di Bursa Efek Indonesia.

\section{DAFTAR PUSTAKA}

Adam, Tim dan Goyal, Vidhan K. 2008. The Investment Opportunity Set And Its Proxy Variables. The journal of Financial Research, Vol. 31 Issue I page 4-63.

Agnes. 2013. Pengaruh Kepemilikan Manajerial, Struktur Modal dan Ukuran Perusahaan Terhadap Nilai Perusahaan. Jurnal Manajemen Universitas Negeri Padang Vol 2, No 01

Agrawal, Surendra P.; Monem Reza M.; dan Ariff, Mohamed. 1996. Price to Book Ratio as a Valuation Model: An Empirical Investigation. FINANCE INDIA Vol. X No. 2, June 1996 Pages - 333-344

Bukit, Rina Br. 2012. Pengaruh Struktur Modal Terhadap Nilai Perusahaan Melalui Profitabilitas Analisis Data Panel Perusahaan Manufaktur di Bursa Efek Indonesia. Jurnal Keuangan Dan Bisnis Vol 4 No3

Bringham, Eugene F dan Houston, Joel F. 2001. Manajemen Keuangan Edisi Kedelapan.Erlangga: Jakarta

Bringham, Eugene F dan Gapenski. 1994. Financial Management. Theory dan Practice.

Chowdhury, Anup dan Chowdhury, Suman Paul. 2010. Impact of capital structure on firm's value: Evidence from Bangladesh. BEH - Business and Economic Horizons Volume 3 Issue 3 pp. 111-122

Damodaran, Aswath. 2002. Investment Valuation: Tools and Techniques for Determining the value of Any Asset $2^{\text {nd }}$ edition. New York: Jhon Wiley \& Sons Inc
Deesomsak, R. and Paudyal, K. and Pescetto, G. 2004. The Determinants of Capital Structure: EvidenceFrom The Asia Pacific Region. Journal of Multinational Financial Management, 14 pp. 387-405.

Fama, Eugene F. 1978. The Effect Of Firm Investment and Financing Decisions on the Welfare of its Security Holders. The American Economics Review Vol. 68 No. 3 (Jun 1978) 272-284

Hardiningsih, Pancawati. 2009. Determinan Nilai Perusahaan. Jurnal Akuntansi Indonesia Vol. 5 No. 2, Juli 2009: 239 - 250

Hasnawati, Sri. 2005. Dampak Set Peluang Investasi Terhadap Nilai Perusahaan Publik di Bursa Efek Jakarta. JAAI Vol 9 No. 2: 117 - 126.

Jensen, Michael C. dan Meckling, William H. 1976. Theory of the Firm: Managerial Behavior, Agency Costs and Ownership Structure. Journal of Financial EconomicsVolume 3, Issue 4, Pages 305-360

Kallapur, Sanjay dan Trombley Mark A. 2001. The Investment Opportunity Set: Determinants, Consequences and Measurement. Managerial Finance Vol. 27 No. 3

Martono dan Harjito, Agus. 2005. Manajemen Keuangan. Yogyakarta: Ekonisia

Nurhayati, Mafizatun. 2013. Profitabilitas, Likuiditas, dan Ukuran Perusahaan Terhadap Kebijakan Dividen \& Nilai Perusahaan Sektor Non Jasa. Jurnal Keuangan dan Bisnis Vol. 5 No. 2 Juli 2013

Oyerogba. 2013. Perceived Relationship between Corporate Capital Structure and Firm Value in the Kenyan Listed Companies. Research Journal of Finance and AccountingVol.4, No.19, 2013

Prasetyo, Aries Heru.2011. Valuasi Perusahaan. Jakarta: PPM

Pratiwi, Natassia Louise. 2011. Pengaruh Struktur Kepemilikan, Likuiditas, Growth, Size, dan Leverage Terhadap Nilai Perusahaan. Skripsi Strata-1 Fakultas Ekonomi Universitas Sebelas Maret

Pratiska, Silka. 2012. Pengaruh IOS, Leverage dan Dividend Yield Terhadap Profitabilitas Dan Nilai Perusahaan Sektor Manufaktur Di BEI. Universitas Udayana

Rompas, Gisela Prisilia. 2013. Likuiditas, Solvabilitas dan Rentabilitas Terhadap Nilai PerusahaanBUMN Yang Terdaftar Di Bursa Efek Indonesia. Jurnal EMBAVol.1 No.3 Hal. 252-262 


\section{Struktur Modal, Investment Opportunity Set, Likuiditas Dannilai Perusahaan}

Lia Uzliawati, Nana Nofianti, \& Dwi Putri Ratnasari

Salvatore, Dominick. 2005. Ekonomi Manajerial dalam Perekonomian Global. Salemba Empat: Jakarta

Scott, Besley dan Eugene F Brigham. 2008. Essential of Managerial Finance. Fourteen Edition. New Jersey:Pearson-Prentice Hall.

Sheikh dan Wang. 2011. Determinants of capital structure An empirical study of firms in manufacturing industry of Pakistan. Managerial Finance Vol. 37 No. 2, 2011 pp. 117-133

Sofyaningsih, Sri dan Hardiningsih, Pancawati. 2011. Struktur Kepemilikan, Kebijakan Dividen, Kebijakan Hutang dan Nilai. Dinamika Keuangan dan Perbankan, Vol. 3, No. 1 Hal: 68 - 87

Soliha, E., Taswan. 2002. Pengaruh Kebijakan Hutang Terhadap NilaiPerusahaan Serta Beberapa Faktor Yang Mempengaruhinya. JurnalEkonomi dan Bisnis, STIE Stikubank Semarang, 1-18.

Sujoko dan Soebiantoro. 2007. Pengaruh Struktur Kepemilikan Saham, Leverage, Faktor Intern Dan Faktor Ekstern Terhadap Nilai Perusahaan. Jurnal Manajemen dan Kewirausahaan, Vol. 9, NO. 1
Sukirni, Dwi. 2012. Kepemilikan Manajerial, Kepemilikan Institusional, Kebijakan Dividen dan Kebijakan Hutang Analisis Terhadap Nilai Perusahaan. Accounting Analysis Journal 1 (2) 2012

Wabwile, Edwin Sawa; Chitiavi, MwalatiSolomon; Alala, Dr. Ondiek B; dan Douglas,Musiega. 2014. Financial Leverage and Performance Variance A Mong Banks. International Journal of Business and Management Invention Volume 3 Issue 4

Yuliani; Zain, Djumilah; Sudarma, Made dan Solimun. 2012. Diversification, IOS, Envinronmental Dynamics \& Firm Value. IOSR Journal of Business and Management Vol 6 Issue 4

http:/ / finance.detik.com/read/2014/05/05/071445/ 2572853/5/kredit-macet-tinggi-btn-ditegur-ojk (diakses tanggal 25/08/2014-07.17 PM)

www.ojk.go.id (diakses pada tanggal 18/07/2014 - 09.10 PM) 